DOI: 10.15290/pnib.2020.05

ks. Andrzej Proniewski

\title{
Biskup Władysław Suszyński - duszpasterz i nauczyciel
}

\section{Wstęp}

Bieżący rok jest w zrozumiały sposób okazją do wspomnienia bp. Władysława Suszyńskiego, jednego z wielkich, choć nie zawsze pamiętanych, postaci Kościoła białostockiego. W tym roku obchodzimy bowiem 50. rocznicę śmierci, także 120. urodzin, nadto 90. rozpoczęcia pracy w Seminarium Wileńskim.

Baza informacyjna, w porównaniu do takich pasterzy białostockich, jak abp R. Jałbrzykowski, czy inni, w tym przypadku jest dość skromna. Choć obok archiwaliów diecezjalnych i seminaryjnych oraz publikacji samego bp. W. Suszyńskiego, znaleźć można także interesujące opracowania. Wspomnieć tu należy biograficzny artykuł ks. T. Krahela zatytułowany Biskup Władysław Suszyński, opublikowany w 2008 roku, w nr. 3 naszego diecezjalnego miesięcznika „W Służbie Miłosierdzia”" ${ }^{1}$ oraz tekst z tego samego roku, pióra wspomnianego autora, umieszczony w „Wiadomościach Kościelnych”, dotyczący zmarłych w 1968 roku biskupów - A. Sawickiego i W. Suszyńskiego². Nadto dysponujemy spisanymi przez ks. R. Kotkowicza wspomnieniami, opublikowanymi w białostockich „Wiadomościach Kościelnych”3. Ksiądz A. Szot z kolei, w publikacji zatytułowanej Pasterze białostockiego Kościoła - ks. Mieczysław Paszkiewicz o biskupach: Adamie Sawickim i Władysławie Suszyńskim, przytacza obszerny biogram tego ostatniego, przygotowany przez śp., wymienionego w tytule, ks. M. Paszkiewicza ${ }^{4}$. Rzecz uzupełniają krótkie biogramy umieszczone

T. Krahel, Biskup Władysław Suszyński, „W Służbie Miłosierdzia” 3 (2008), s. 14.

2 Idem, W czterdziestą rocznicé śmierci bp. Adama Sawickiego i bp. Władysława Suszyńskiego, „Wiadomości Kościelne Archidiecezji Białostockiej", 4 (2008), s. 163-171.

3 R. Kotkowicz, Ksiądz biskup Władysław Suszyński 1898-1968. Wspomnienia, „Wiadomości Kościelne Archidiecezji Białostockiej" 4 (1978), s. 40-48.

4 A. Szot, Pasterze białostockiego Kościoła - ks. Mieczysław Paszkiewicz o biskupach: Adamie Sawickim i Władysławie Suszyńskim, „Studia Teologiczne. Białystok, Łomża, Drohiczyn”, 27 (2009), s. 493-499. 
w różnych wydawnictwach, sporządzone przez bp. Edwarda Ozorowskiego ${ }^{5}$ oraz przez ks. Piotra Niteckiego ${ }^{6}$.

\section{1. Życiorys}

Przyszły Biskup urodził się w Janowie, miejscowości położonej na trasie pomiędzy Sokółką a Korycinem, 22 stycznia 1898 roku, z trudniących się rolnictwem rodziców, Aleksandra, który nadto dorabiał w fachu rymarza i Julii z domu Solnik. Był drugim z sześciorga dzieci. Nauki pobierał kolejno w szkole w miejscowości rodzinnej, następnie w Sokółce i Grodnie. Ksiądz M. Paszkiewicz dodaje informację, jakoby po przerwaniu w 1914 roku nauki z powodu wojny, miał jako eksternista ukończyć szkołę średnią i uzyskać świadectwo dojrzałości w Wilnie ${ }^{7}$. Siostrzenica Biskupa z kolei, że po skończeniu "gorodzkowo uczyliszcza" w Sokółce, wujek przez cztery lata uczęszczał do gimnazjum w Grodnie ${ }^{8}$. Na tej informacji poprzestaje także ks. T. Krahel ${ }^{9}$. Jakkolwiek by nie patrzeć na tę rozbieżność, pewne jest, iż Władysław Suszyński w roku 1916 wstąpił do wileńskiego Seminarium Duchownego.

Okres studiów seminaryjnych alumna W. Suszyńskiego w superlatywach komentuje ks. M. Paszkiewicz:

Jako alumn był pilny, sumienny, systematyczny w pracy. Wiedzę cenił i ustawicznie ją pogłębiał. Posiadał świetną pamięć i nieprzeciętne zdolności do spekulacji teologicznej i filozoficznej. Toteż egzaminy składał bardzo dobrze. Obok tego pracował nad sobą, kształtował charakter, urabiał cnoty. Miał więc opinię wzorowego alumna pod względem nauki i życia wewnętrznego. Pięcioletni kurs nauki w ówczesnym [Wyższym] Seminarium Duchownym ukończył z wyróżnieniem ${ }^{10}$.

Po ukończeniu formacji seminaryjnej, 26 maja 1921 roku z rąk ówczesnego biskupa wileńskiego, beatyfikowanego w 1987 roku, bł. Jerzego Matulewicza, otrzymał święcenia kapłańskie.

Dwa kolejne lata wypełniły studia teologiczne na bardzo młodej uczelni, dziś świętującym swoje stulecie, Katolickim Uniwersytecie Lubelskim, uwieńczone licencjatem z teologii fundamentalnej 18 października 1923 roku. Z czasem studiów lubelskich zbiegło się też tragiczne doświadczenie straty rodziców,

5 E. Ozorowski, Suszyński Władysław, [w:] Archidiecezjalne Wyższe Seminarium Duchowne w Białymstoku 1945-1980, Białystok 1981, s. 125-126; Idem, Suszyński Władysław, [w:] L. Grzebień red., Słownik Polskich Teologów Katolickich, t. VII, Warszawa 1983, s. 197-198.

$6 \quad$ P. Nitecki, Suszyński Władysław, [w:] P. Nitecki, Biskupi Kościoła w Polsce w latach 965-1999. Słownik biograficzny, Warszawa 2000, s. 424.

7 A. Szot, Pasterze białostockiego Kościoła - ks. Mieczysław Paszkiewicz o biskupach: Adamie Sawickim i Władysławie Suszyńskim, s. 493.

$8 \quad$ R. Kotkowicz, Ksiądz biskup Władysław Suszyński 1898-1968. Wspomnienia , s. 40.

9 T. Krahel, Biskup Władysław Suszyński, „W Służbie Miłosierdzia” 3 (2008), s. 14; Idem, W czterdziesta rocznicę śmierci bp. Adama Sawickiego i bp. Władysława Suszyńskiego, s. 168.

10 A. Szot, Pasterze białostockiego Kościoła - ks. Mieczysław Paszkiewicz o biskupach: Adamie Sawickim i Władysławie Suszyńskim, s. 493. 
zmarłych kolejno w roku 1922 (ojciec) i 1923 (matka). Nie zakłóciło to jednak drogi rozwoju intelektualnego, gdyż jeszcze w tym samym roku, podjął formację filozoficzno-teologiczną w Paryżu. Odbyte pod kierunkiem Jacques'a Maritaine'a studia filozoficzne zamknął w 1927 roku obroną doktoratu na temat Idei Boga u Kartezjusza w świetle tomizmu. Ocenę zarówno studiów, jak i dysertacji podsumowują słowa samego J. Maritaine'a: „Francuzi, uczcie się od tego Polaka, jak pisać po francusku i opracowywać zagadnienia naukowe"11.

Po ukończeniu studiów i pobycie w Wenecji, w celu polepszenia zdrowia nadwyrężonego w Paryżu, powrócił do Wilna, gdzie od abp. R. Jałbrzykowskiego otrzymał zadanie objęcia świeżo utworzonej placówki duszpasterskiej w Jaźnie. Kolejne zmiany w życiu przyniósł rok 1928, w którym został odwołany do Wilna, mianowany sekretarzem metropolity oraz profesorem, a także prefektem Seminarium Duchownego. W roku 1929 w Wilnie opublikował krótką rozprawę nt. Jednostka a społeczeństwo. Przyczynek do studiów socjologicznych. Kolejne lata łączą się, oprócz zadań seminaryjnych, z pracą uniwersytecką, przerwaną przez wybuch II wojny światowej.

Zawierucha wojenna przyniosła wpierw okupację sowiecką i groźbę zamknięcia Seminarium, któremu udaje się jakoś przetrwać ponad dwa lata. A także zmianę okupanta z czerwonego na brunatnego. W międzyczasie (28 sierpnia 1940) ks. W. Suszyński zostaje podniesiony do godności kanonika gremialnego Kapituły Bazyliki Metropolitalnej Wileńskiej. Wówczas to ks. W. Suszyński, tak jak i inni wykładowcy oraz alumni, aresztowany przez Niemców 3 marca 1942 roku, trafił do słynnego wileńskiego więzienia na Łukiszkach, po nieco ponad dwóch tygodniach (19 marca 1942) został internowany w Wiłkowyszkach i 17 października tegoż roku osadzony w obozie pracy w Szałtupiu. Zwolniony 31 marca 1943 roku wrócił na krótko do Wilna, po czym ukrywał się w różnych miejscach, by wrócić w rodzinne strony 16 maja 1945 roku.

W nowej, powojennej rzeczywistości, już w Białymstoku, powrócił do pracy seminaryjnej, od 1946 roku w charakterze rektora. 5 maja 1945 roku został ogłoszony wiceoficjałem, a w roku 1947 oficjałem Sądu Arcybiskupiego.

19 maja 1948 roku papież Pius XII wyznaczył go na biskupa pomocniczego przy Metropolicie R. Jałbrzykowskim i biskupa tytularnego Taborry. 9 maja 1948 roku, w ówczesnym białostockim kościele farnym, przyjął sakrę biskupią z rąk Prymasa kard. Augusta Hlonda, któremu jako współkonsekratorzy towarzyszyli abp R. Jałbrzykowski i bp Stanisław Łukomski z Łomży.

Gdy 19 czerwca 1955 roku odejdzie do wieczności abp R. Jałbrzykowski, rezydująca, jak pozostałe instytucje kościelne, w Białymstoku, Kapituła wileńska dokona wyboru bp. W. Suszyńskiego na wikariusza kapitulnego Archidiecezji w Białymstoku. Z braku koniecznego wówczas zatwierdzenia tego wyboru ze strony władz państwowych, zrezygnuje on z tej funkcji na rzecz ks. prałata Adama Sawickiego, najpierw wikariusza kapitulnego, a od 1963 roku biskupa

11 Ibidem, s. 499. 
- administratora apostolskiego Archidiecezji w Białymstoku. Wówczas to, 20 maja 1963 roku, bp W. Suszyński zostanie również wikariuszem generalnym. Po trzynastu latach, po śmierci bp. A. Sawickiego, 21 maja 1968 roku kapituła ponownie wybierze go wikariuszem kapitulnym. Niebawem (6 lipca 1968) przyjdzie także mianowanie przez Stolicę Apostolską administratorem apostolskim znajdującej się w granicach Polski części Archidiecezji Wileńskiej.

Rok 1968 okazał się jednak także, po ludzku sądząc, feralnym. Gdy bowiem 20 października bp W. Suszyński będzie uczestniczył w obchodach 50-lecia KUL-u, odbywających się na dziedzińcu uczelni, doświadczy przeziębienia. Pomimo tej niedogodności, nazajutrz odbędzie jeszcze spotkanie z księżmi studiującymi w Lublinie. Bezpośrednio stamtąd uda się do Warszawy, na obrady Episkopatu Polski w dniach 22-23 października. Tu nastąpi dramatyczny przełom. 24 października rano, towarzyszący Biskupowi ks. Henryk Glinko odwiezie chorego do szpitala Sióstr Elżbietanek przy ul. Puławskiej w Warszawie, gdzie wycieńczony chorobą, dotknięty nadto stanem przedzawałowym, odda ducha w uroczystość Chrystusa Króla, 27 października, o godz. 12.45.

Szczątki powszechnie szanowanego Biskupa spoczęły w grobowcu przy starym kościele farnym $\mathrm{w}$ Białymstoku, podczas liturgii pogrzebowej sprawowanej w prokatedrze białostockiej, pod przewodnictwem Sługi Bożego kard. Stefana Wyszyńskiego.

\section{Duszpasterz}

Chcąc przywołać obraz księdza, potem biskupa, W. Suszyńskiego - duszpasterza, dla pełnego oglądu, powinniśmy sięgnąć do szczegółowych opinii i ocen pracy na konkretnych odcinkach jego drogi duszpasterskiego posługiwania. Nie dysponujemy, niestety, takim materiałem, a przynajmniej nie jest on łatwo dostępny. A jednak próbując odpowiedzieć na pytanie o taki obraz, także nie pozostajemy bezsilni. Dysponujemy przecież przywoływanymi już wspomnieniami. Jaki obraz się z nich wyłania?

Przede wszystkim napotykamy na informacje, iż ks. W. Suszyński duszpasterstwem zajmował się już w czasie studiów francuskich. Ksiądz M. Paszkiewicz napisze, iż „podczas studiów paryskich wszystkie swe wakacje i ferie świąteczne poświęcał (przeważnie $w$ diecezjach Bourges [Burż] i Cambrai[Kambre]) pracy duszpasterskiej nad uchodźcami polskimi i katechizacji dzieci i młodzieży"12. Podobnie ks. R. Kotkowicz pisał o tym okresie:

Z czasu pobytu we Francji - oprócz sukcesów naukowych - należy odnotować wspaniałe osiągnięcia w dziedzinie duszpasterstwa wśród emigrantów polskich. Ks. Wł. Suszyński wszystkie swoje chwile, wolne od zajęć studenckich poświęca pracy wśród Polaków, emigrantów w diecezji Bourges i Cambrai: katechizuje,

12 A. Szot, Pasterze białostockiego Kościoła - ks. Mieczysław Paszkiewicz o biskupach: Adamie Sawickim i Władysławie Suszyńskim, s. 493. 
przygotowuje do sakramentów św., głosi starannie opracowane, oparte na znajomości literatury polskiej kazania, stając się dla tych ludzi ciężko pracujących, tęskniących za krajem i najbliższymi źródłem radości, przyjacielem, powiernikiem ich spraw i przeżyć. Gdy w roku 1927 powraca do kraju, pozostawia we Francji grono przyjaciół i łzy rozstania ${ }^{13}$.

Na następny etap duszpasterskiego zaangażowania pośle młodego doktora filozofii abp R. Jałbrzykowski, wręczając mu 16 sierpnia 1927 roku $^{14}$ nominację do posługi prefekta szkół i obsługi kościoła w placówce duszpasterskiej Jazno, umiejscowionej około $250 \mathrm{~km}$ na północny wschód od Wilna. Była to nominacja na swój sposób zaskakująca. Co prawda, miejscowość posiadała rangę gminną, lecz nie parafialną, a świeżo pobudowany kościół obsługiwany był przez duszpasterzy z Dzisny i był świątynią rektoralną. Był to czas formowania w tym miejscu nowej parafii - dlatego ks. T. Krahel mówi o "stanowisku rektora” i dopiero o zamyśle Arcybiskupa stworzenia tam parafii ${ }^{15}$, ks. M. Paszkiewicz o nominacji nie na rektora, lecz ",administratora" nowo powstałej placówki ${ }^{16}$, zaś ks. R. Kotkowicz napisze wprost: „1 VIII 1927 r. otrzymuje nominację na administratora parafii i prefekta szkół położonych na terenie parafii Jazno"17. Ksiądz W. Suszyński okazał się tam pierwszym duszpasterzem. Ksiądz T. Krahel powiada, że „...znalazł się [ks. W. Suszyński] w trudnej sytuacji materialnej. Nie miał etatu szkolnego, posługi parafialne (śluby i pogrzeby) sprawował proboszcz z Dzisny, a intencji mszalnych miał w miesiącu tylko dwie - trzy"18. Efektem było między innymi skierowane do Kurii pismo, datowane na 2 grudnia 1927 roku, z prośbą o ustanowienie przez Kuratorium Okręgu Szkolnego etatu prefekta szkół lub przyznanie stosownej pensji ${ }^{19}$.

Ksiądz R. Kotkowicz zapamiętał opowieść samego bohatera [naszego wywodu] na temat warunków pracy w Jaźnie i przekazuje ją następującymi słowami:

...mówił, że najczęstszym środkiem komunikacji z parafianami był grzbiet konia, którego kupił lub dwukółka, niezbyt dobrze wyresorowana, trzęsąca po wybojach gruntowych dróg i bezdroży. Opinia wśród księży diecezjalnych o tej placówce była jednoznaczna: „dziura zabita dechami, gdzie diabeł mówi dobranoc"20.

13 R. Kotkowicz, Ksiądz biskup Władystaw Suszyński 1898-1968. Wspomnienia, s. 41.

14 Informacja za T. Krahel, Biskup Władysław Suszyński, s. 14. Zarówno ks. R. Kotkowicz, jak i M. Paszkiewicz wspominają, iż nominację otrzymał 1 sierpnia. R. Kotkowicz, Ksiądz biskup Władysław Suszyński 1898-1968. Wspomnienia, s. 41; A. Szot, Pasterze białostockiego Kościoła - ks. Mieczysław Paszkiewicz o biskupach: Adamie Sawickim i Władysławie Suszyńskim, s. 494.

15 T. Krahel, Biskup Władysław Suszyński, s. 14; Idem, W czterdziesta rocznicé śmierci bp. Adama Sawickiego i bp. Władysława Suszyńskiego, s. 169.

16 A. Szot, Pasterze białostockiego Kościoła - ks. Mieczysław Paszkiewicz o biskupach: Adamie Sawickim i Władysławie Suszyńskim, s. 494.

17 R. Kotkowicz, Ksiądz biskup Władystaw Suszyński 1898-1968. Wspomnienia, s. 41.

18 T. Krahel, Biskup Władysław Suszyński, s. 14; Idem, W czterdziesta rocznicé śmierci bp. Adama Sawickiego i bp. Władystawa Suszyńskiego, s. 169.

19 Ibidem.

20 R. Kotkowicz, Ksiądz biskup Władysław Suszyński 1898-1968. Wspomnienia, s. 41. 
Stąd i zapamiętane przekonanie wielu księży, że może ks. W. Suszyński czymś „podpadł”, iż trafił do takiego miejsca ${ }^{21}$. Z czasem, jak się zdaje, uznano, iż musiała to być swego rodzaju próba ${ }^{22}$. Po jej szybkim zakończeniu, już w następnym roku, konkretnie 10 sierpnia 1928 roku, arcybiskup powoła go do Wilna, posyłając do zadań naukowo-wychowawczych w Seminarium Duchownym i wyznaczając na swojego sekretarza.

Okres doświadczenia, nazwijmy to - parafialnego, chociaż krótki, okazał się owocny. Chyba najlepiej scharakteryzował go, wspominany już wielokrotnie, ks. M. Paszkiewicz:

Doprowadził tu do porządku domek przeznaczony na plebanię. Zaopatrzył w potrzebne utensylia swój kościółek, zorganizował stałe nabożeństwa, nawiązał życzliwy, duszpasterski kontakt z miejscową ludnością i liczną tu szlachtą polską, dziećmi i młodzieżą. Kiedy więc wyjechał stąd do Wilna, pozostawił po sobie serdeczny żal i najlepsze wspomnienia ${ }^{23}$.

Odwołujący się natomiast do tego samego okresu, ks. R. Kotkowicz, zdaje się iść już torem wyraźnie panegirycznym, by nie powiedzieć hagiograficznym. Mimo to, mile się czyta o tym, jak

posłuszny woli swego ordynariusza [ks. W. Suszyński] staje w pierwszym szeregu duszpasterzy, aby swoją wiedzą, mądrością, życiowym doświadczeniem wyniesionym z kontaktów duszpasterskich we Francji, służyć ludowi, budować wspólnotę wiary i jedność narodu, budzić poczucie wolności wolnego, niepodległego człowieka. Przez rok pobytu na placówce w Jaznie ks. Suszyński stworzył trwałe podstawy przyszłej pracy duszpasterskiej i oświatowej. Zadbał o wyposażenie kościoła i plebanii, utrwalił porządek nabożeństw, zorganizował wspólnotę parafian oddanych kościołowi, ugruntowanych $\mathrm{w}$ wierze i polskości. Zadziwia obfitość owoców tak krótkotrwałego czasu pracy, ale ks. Wł. Suszyński zasłużył nie tylko na podziw i uznanie swej pracy przez współbraci kapłanów i ks. Arcybiskupa, lecz prawdziwe przywiązanie i żal parafian z powodu rozstania. Powtórzyła się sytuacja jego kontaktów duszpasterskich we Francji, podobnie jak tam, tak i tu, na ojczystej ziemi jego wyjazdowi z placówki towarzyszyła ludzka, serdeczna wdzięczność ${ }^{24}$.

Po wyjeździe z Jazna trudno mówić o jakimś systematycznym duszpasterstwie. Pochłaniała go praca dydaktyczna i służba w kościelnym sądzie, choć wspomnieć można funkcję moderatora Sodalicji Mariańskiej Pań, którą pełnić będzie do 16 grudnia 1930 roku $^{25}$.

Następny etap duszpasterstwa związany jest już z posługą biskupią. Najpierw w charakterze biskupa pomocniczego przy abp. R. Jałbrzykowskim, aż

21 R. Kotkowicz, Ksiądz biskup Władysław Suszyński 1898-1968. Wspomnienia, s. 42.

22 Ibidem; T. Krahel, Biskup Władysław Suszyński, s. 14; Idem, W czterdziestą rocznicé śmierci bp. Adama Sawickiego i bp. Władysława Suszyńskiego, s. 169.

23 A. Szot, Pasterze białostockiego Kościoła - ks. Mieczysław Paszkiewicz o biskupach: Adamie Sawickim i Władysławie Suszyńskim, s. 494.

24 R. Kotkowicz, Ksiądz biskup Władysław Suszyński 1898-1968. Wspomnienia, s. 42.

25 T. Krahel, Biskup Władysław Suszyński, s. 14; Idem, W czterdziesta rocznicę śmierci bp. Adama Sawickiego i bp. Władysława Suszyńskiego, s. 169. 
do jego śmierci w Białymstoku (19 czerwca 1955). Później, gdy zabrakło akceptacji władz państwowych dla wyboru osoby bp. W. Suszyńskiego na wikariusza kapitulnego Archidiecezji w Białymstoku, posługa przy nowym wikariuszu kapitulnym, ks. prałacie (a od 1963 roku biskupie) Adamie Sawickim. Biskup W. Suszyński przez kilka miesięcy roku 1968 pracował w charakterze administratora apostolskiego.

Najogólniejsze podsumowanie tej posługi można zawrzeć w słowach: „wypełniał obowiązki biskupie", tzn. głosił Słowo Boże, wizytował parafie, udzielał sakramentu bierzmowania.

Nie można pominąć faktu, że moc do pracy czerpał z gorliwego życia duchowego. Wspominający go podkreślają sumienność w modlitwie. Ksiądz R. Kotkowicz wspomina:

Jako kapłan starał się we właściwym czasie odmówić oficjum brewiarzowe, pobożnie, z wielkim skupieniem celebrował mszę św., nie znosił niedbalstwa czy powierzchowności w dziedzinie tak ważnej, jak służba Boża w liturgii. [...] Ci, którzy spotykali się z Ks. Biskupem na każdy dzień, dają świadectwo, że nigdy nie opuścił modlitwy różańcowej, przygotowania i dziękczynienia po mszy św., lektury duchowej ${ }^{26}$.

Duchowość, którą reprezentował ks. bp W. Suszyński oddziaływała nie tylko na jego misję duszpasterską. Ożywiała ona także jego gorliwość naukową i czyniła go przykładem nauczyciela.

\section{Nauczyciel}

Osobny rozdział w dziejach bp. W. Suszyńskiego stanowi jego zaangażowanie na polu naukowo-dydaktycznym. By objąć ten temat, wspomnimy najpierw kwestię funkcji i stanowisk uczelnianych, by w końcu przedstawić, jak zapisał się w oczach studentów i ukazać zarys jego zainteresowań naukowych.

\section{A. Stanowiska uczelniane}

Jak już wspomnieliśmy przytaczając życiorys naszego bohatera, otrzymał on solidne wykształcenie, jako wybitny student i doktorant J. Maritaine'a. Po obronie pracy, powrocie do kraju i doświadczeniu duszpasterskiemu w Jaznie, pierwszym stanowiskiem uczelnianym okaże się funkcja prefekta i profesora Seminarium Duchownego w Wilnie, którą objął na mocy nominacji z 10 sierpnia 1928 roku, a po roku (6 sierpnia 1929) został jego wicerektorem. W 1929 roku objął także obowiązki zastępcy profesora Wydziału Teologicznego Uniwersytetu Stefana Batorego w Wilnie. Prowadził wykłady z dziedzin filozoficznych,

26 R. Kotkowicz, Ksiądz biskup Władysław Suszyński 1898-1968. Wspomnienia, s. 45. 
takich, jak historia filozofii, teodycea, kosmologia. Prowadził także seminarium naukowe filozofii chrześcijańskiej.

W czasie II wojny światowej, aż do momentu uwięzienia (3 marca 1942) pracował w Seminarium. Po zakończeniu wojny, już w nowej, białostockiej rzeczywistości, 1 sierpnia 1945 roku został profesorem działającego od 5 maja tego roku Seminarium Duchownego, co prawda jeszcze uważanego za wileńskie, ale już rezydującego w naszym mieście. Niebawem, w roku 1946, po odejściu dotychczasowego rektora, ks. prof. Ignacego Świrskiego do posługi biskupiej w Siedlcach, został mianowany także jego rektorem. Wykładał przedmioty filozoficzne: historię filozofii, teodyceę, kosmologię, a po odejściu ks. M. Klepacza i I. Świrskiego, przez pewien czas także metafizykę i psychologię oraz prawo kanoniczne.

Zaangażowanie uniwersyteckie wymagało ciągłego podnoszenia kwalifikacji naukowych. Owocem tego było przygotowanie rozprawy habilitacyjnej zatytułowanej Idea Boga w myśli M. Schelera, niestety bezpowrotnie utraconej w zawierusze wojennej i uwięzieniu autora. Mimo nawału pracy i trudnych, powojennych okoliczności, 22 czerwca 1946 roku przeprowadził przewód habilitacyjny na Wydziale Teologicznym USB w Białymstoku, na podstawie dorob$\mathrm{ku}$ i dysertacji pt. Idea Boga w filozoficznym rozwoju św. Augustyna, co nie przyniosło jednak oczekiwanego rezultatu. Praca nie została zatwierdzona przez Ministerstwo Oświaty, w związku z niejasnym statusem Wydziału. Ponowił starania w następnym roku, przeprowadzając kolokwium na Wydziale Teologicznym w Warszawie. Ksiądz T. Krahel wprawdzie zilustrował to stwierdzeniem: „Wszystko wskazuje na to, że i tej habilitacji nie uznano" ${ }^{27}$. Napotykamy tu jednak na problem, gdyż w krótkim życiorysie, spisanym odręcznie przez samego ks. W. Suszyńskiego, znajdujemy takie zdanie: „Stopień Docenta Filozofii Chrześcijańskiej uzyskałem na Wydziale Teologii Katolickiej Uniwersytetu Warszawskiego w r. 1947"28. Dokument, opatrzono datą 15 listopada 1947 roku. Być może, że zdanie to ks. W. Suszyński spisał zatem jeszcze oczekując na zatwierdzenie tytułu, które niekoniecznie musiało nadejść. Jednak na podstawie wspomnienia ks. M. Paszkiewicza, który mówi wprost, że przyszły biskup „....habilitował się na Wydziale Teologicznym [Uniwersytetu] w Warszawie dnia 28 czerwca 1947 r. na podstawie pracy pt. Idea Boga w filozoficznym rozwoju św. Augustyna"29 i według ks. R. Kotkowicza ${ }^{30}$ sprawa wymaga doprecyzowania. Abstrahując od problemu tego konkretnego stopnia, trzeba zaznaczyć, że z czasem, zmuszony okolicznościami historycznymi, następnie rektorstwem, a także nominacją biskupią i związanymi z tym obowiązkami, działalność

27 T. Krahel, Biskup Władysław Suszyński, s. 14; Idem, W czterdziesta rocznicę śmierci bp. Adama Sawickiego i bp. Władysława Suszyńskiego, s. 170.

28 Ks. Władysław Suszyński, odręczny życiorys, teczka AAB, rkps.

29 A. Szot, Pasterze białostockiego Kościoła - ks. Mieczysław Paszkiewicz o biskupach: Adamie Sawickim i Władysławie Suszyńskim, s. 495.

30 R. Kotkowicz, Ksiądz biskup Władysław Suszyński 1898-1968. Wspomnienia, s. 43. 
dydaktyczną ograniczy tylko do wykładów z prawa kanonicznego, które będzie prowadził.

\section{B. Styl i charakter pracy}

Jeśli zapytamy o styl pracy ks. W. Suszyńskiego na niwie nauczycielskiej, to można określić go wizjonerem, któremu zależało na solidnej formacji podopiecznych. Powiedziano o nim, że

jako świetny analityk, w przyszłościowych prognozach dostrzegał potrzebę zapewnienia dla potrzeb archidiecezji liczby kapłanów oddanych nie tylko posłudze duszpasterskiej, lecz także posłudze na innych stanowiskach, wymagających specjalistycznej wiedzy teologicznej, filozoficznej, prawniczej; zdawał sobie sprawę z tego, że współczesność charakteryzować się będzie dynamicznym rozwojem nauki, a to siła faktu narzuci na kapłanów obowiązek wszechstronnego rozwoju intelektualnego, ciągłego studium różnych dyscyplin wiedzy ${ }^{31}$.

Co stawiał za cel formacji swoich studentów, to realizował także sam, stając się żywym przykładem właściwej drogi. Niech obrazem tego będzie zdanie ks. S. Piotrowskiego:

chociaż już tyle lat wykładał, znał podręcznik na pamięć, przed każdym wykładem można go było, w godzinach wieczornych zastać nad przygotowaniem wykładu na dzień następny. Jakaż sumienność, poszanowanie słuchaczy, a nam młodym wówczas profesorom, cóż za poglądowa lekcja, jak wypełniać powierzony obowiązek ${ }^{32}$.

Nie dziwi, że i przywoływany już wielokrotnie ks. M. Paszkiewicz doda: ,jako profesor, przy swym wielkim przygotowaniu naukowym i zdolnościach, był niezmiernie sumienny i pracowity. Materiał podawał w sposób jasny i zwięzły. Umiał zainteresować słuchacza, pobudzić do samodzielnej pracy"33.

Godne zauważenia jest to jak profetyczny okaże się jako rektor w swoich spostrzeżeniach. Już wówczas konsultowany przez Komisję wybraną przez ks. Rektorów Seminariów Duchownych w Polsce do opracowania projektu nowego Ratio Studiorum napisze 26 listopada w roku 1966:

Odnośnie wprowadzenia do sześcioletnich studiów filozoficzno-teologicznych tak zwanego "roku wstępnego" sądzę, że taki rok byłby pożyteczny, gdyby na nim wykładano języki biblijne: hebrajski, grecki, ponadto łacinę, jakiś język nowożytny, katolickie naświetlenie historii literatury polskiej, wstęp do filozofii oraz pewne zagadnienia $\mathrm{z}$ dziedziny nowoczesnej fizyki. Te przedmioty odciążyłyby pierwsze dwa kursy filozoficzne i ułatwiłyby lepsze przyswojenie filozofii chrześcijańskiej. Jednocześnie jednak obawiam się, czy dodanie nowego siódmego roku nie przyczyni się do zmniejszenia ilości kandydatów do Seminariów. Następnie uważam, że wprowadzenie kursu wstępnego, chociaż może ułatwi pracę alumnów na kursach filozoficznych, zbyt wielkiego pożytku nie przyniesie,

\footnotetext{
$31 \quad$ Ibidem, s. 44.

32 Ibidem, s. 46.

33 Ibidem.
} 
ponieważ nowoczesna młodzież nie ma zamiłowania do filozofii i jej nie wykorzystuje w swej pracy duszpasterskiej. Na zaznajomienie się zaś z terminologią scholastyczną, potrzebną do zrozumienia teologów scholastycznych, to co młodzież zdobywa przy obecnym Ratio Studiorum w zupełności jej wystarcza ${ }^{34}$.

Kontynuuje rektor Suszyński:

Ponieważ nowoczesna młodzież ma zamiłowanie do techniki i sportu, należałoby raczej obmyśleć, $\mathrm{w}$ jaki sposób ta młodzież ma wykorzystywać nowoczesne środki techniczne: radio, telewizję, aparaty filmowe i fotograficzne oraz wszelkiego rodzaju sporty w pracy duszpasterskiej, żeby do obecnej masowej kultury wprowadzić kulturę religijną" ${ }^{35}$.

Jego realne spojrzenie na formację seminaryjną odnosiło się także do roku pastoralnego, który zamierzano wprowadzić w seminariach. W tej sprawie napisze:

W sprawie zaś roku pastoralnego sądzę, że nie należy przerywać studiów, by zdobyć praktykę duszpasterską. Uważam, że otrzymane w końcu piątego roku studiów święcenia diakonatu umożliwią alumnowi w czasie letnich wakacji oraz ferii Bożego Narodzenia i Wielkanocy zdobycie niezbędnej praktyki duszpasterskiej, potrzebnej mu w pierwszych latach kapłaństwa ${ }^{36}$.

Takie rozwiązanie zastosowano i jest ono praktykowane do dzisiaj w kształceniu seminaryjnym.

\section{Zainteresowania naukowe}

Spośród zagadnień naukowych, które bp Suszyński rozwijał, na uwagę zasługuje jego jedyne znane mi wydane drukiem dziełko, wówczas jeszcze ks. dr. Wł. Suszyńskiego, opublikowane w 1929 roku: Jednostka a społeczeństwo. Przyczynek do studiów socjologicznych, Wilno 1929, liczące 20 stron.

Autor snuje refleksję dotyczącą reformy społeczeństwa, w którym odchodzi się od koncepcji narodowościowych na rzecz kosmopolityzmu i humanitaryzmu szeroko pojmowanego jako motywu łączącego obywateli we wszechświecie. „Promuje się - twierdzi autor - wszechświat jako ojczyznę albowiem bycie obywatelem wszechświata uchodzi za najszlachetniejszy poryw, godny człowieka jako istoty rozumnej" ${ }^{37}$. Autor krytykuje, że

wskutek realizacji takich pragnień zanika rozumienie podstawowej definicji czym jest społeczeństwo jako realność społeczna. W konsekwencji dochodzi do zaniku istnienia narodu jako zjednoczonej wspólnoty osób, co przynosi podziały w obrębie społeczeństwa dotychczas rozumianego jako jedno na odrębne grupy czego przykładem może być podział narodu niemieckiego po układzie Westfalskim

\footnotetext{
34 W. Suszyński, Do Komisji wybranej przez ks. Rektorów Seminariów Duchownych w Polsce we wrześniu 1965 roku, która ma opracować projekt nowego Ratio Studiorum, rkps.

35 Ibidem.

36 Ibidem.

37 W. Suszyński, Jednostka a społeczeństwo. Przyczynek do studiów socjologicznych, Wilno 1929, s. 3.
} 
na liczne niezależne państewka. Wskutek takiego działania dochodzi do zaniku korporacji ${ }^{38}$.

Aby zapobiec kompletnemu rozpadowi społeczeństw, Suszyński zachęca do zróżnicowanych odniesień określających tożsamość narodu zarówno na poziomie uczuć narodowych, czy wspólnej historii, celowości działań, godności narodowej, a więc doświadczenia jak też wiedzy ${ }^{39}$. Człowiek poza obrębem narodu jest niezrozumiały. Jednostka jest złączona ściśle z narodem poprzez wspólnotę języka, obyczajów, praw i instytucji, na życie i śmierć ${ }^{40}$. Wypowiada wyraźny sprzeciw wobec poglądów Rousseau, który o narodzie zapisał: „jest on garścią znikomych bytów umieszczonych w zakątku ziemi"41.

Swoje poglądy na temat potrzeby istnienia narodu i struktur tworzących go opiera na poglądach ekonomistów, socjologów i filozofów kręgu języka niemieckiego, pośród których wyróżnia Justusa Mosera (1720-1794), Adama Heinricha Müllera (1779-1829), Friedricha Lista (1789-1846), Wilhelma Roschera (1817-1894), Karla Gustava Adolfa Kniesa (1821-1898), Johanna Caspara Bluntschli (1808-1881).

Krytykuje poglądy Georga Wilhelma Friedricha Hegla (1770-1831) i polemizuje z Emilem Durkheimem (1858-1917), broniąc podstaw metafizyki tomistycznej. Co więcej, rozwija zagadnienia metafizyki św. Tomasza ukazując jej niezastąpiony charakter w rozumieniu szeroko pojętej rzeczywistości ${ }^{42}$, w tym w sposób szczególny społeczeństwa. Pisze:

Jakiego rodzaju jedność posiada byt społeczny? Byt społeczny posiada jedność transcendentalną, ponieważ jest pewnego rodzaju całością, a jako całość musi być czemś niepodzielnym. Jedność społeczeństwa nie jest jednością prostoty, lecz jednością złożoności, ponieważ całość społeczna, aczkolwiek nie jest podzielona, jest jednak podzielna, czyli może być podzielona. Jedność złożoności w społeczeństwie nie jest substancjalna, ponieważ części, poszczególni ludzie wchodząc do społeczeństwa, nie zatracają swego własnego istnienia, ani też niezależności w działaniu tak, jak ją zatracają części w substancji. Nie posiadając jedności substancjalnej, społeczeństwo nie jest bytem substancjalnym, lecz bytem przypadłościowym o złożoności przypadłościowej ${ }^{43}$.

Nie czas tutaj i miejsce na rozwijanie idei zawartej w lekturze, zachęcam do zapoznania się z jej treścią, gdyż posiadamy ją w zbiorach archiwalnych i bibliotecznych.

Choć, jak czytamy u jednego z autorów, mógł on „stać się twórcą polskiej szkoły filozofii tomistycznej" ${ }^{44}$, rozstał się z drogą samodzielnej kariery na-

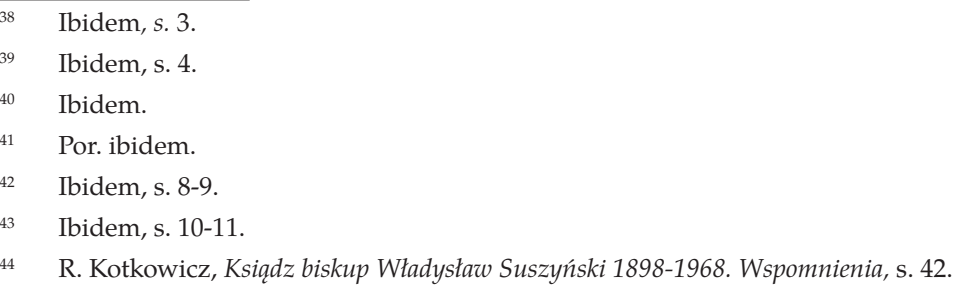


ukowej, by swój nieprzeciętny intelekt zaangażować w te dziedziny, które były w tym czasie bardziej potrzebne Kościołowi. Można postawić pytanie: czy można o nim powiedzieć jako o zmarnowanym talencie naukowym? Z pewnością nie. W perspektywie Królestwa Bożego okazał się niewątpliwie człowiekiem Kościoła i mądrości, która przekracza, skądinąd wzniosłe ramy uniwersyteckie. Przez swoje zaangażowanie tak duszpasterskie, jak i naukowe, tak w dziedziny duchowe, jak i te całkiem przyziemne, zapisał się jako nauczyciel przede wszystkim życia chrześcijańskiego, pokory i miłości.

\section{Bibliografia}

Kotkowicz R., Ksiądz biskup Władysław Suszyński 1898-1968. Wspomnienia, „Wiadomości Kościelne Archidiecezji Białostockiej" 4 (1978).

Krahel T., Biskup Władysław Suszyński, „WW Służbie Miłosierdzia” 3 (2008).

Krahel T., W czterdziesta rocznicé śmierci bp. Adama Sawickiego i bp. Władysława Suszyńskiego, „Wiadomości Kościelne Archidiecezji Białostockiej”, 4 (2008).

Nitecki P., Suszyński Władysław, [w:] P. Nitecki, Biskupi Kościoła w Polsce w latach 9651999. Słownik biograficzny, Warszawa 2000.

Ozorowski E., Suszyński Władysław, [w:] Archidiecezjalne Wyższe Seminarium Duchowne w Białymstoku 1945-1980, Białystok 1981.

Ozorowski E., Suszyński Władysław, [w:] L. Grzebień red., Słownik Polskich Teologów Katolickich, t. VII, Warszawa 1983.

Suszyński W., Do Komisji wybranej przez ks. Rektorów Seminariów Duchownych w Polsce we wrześniu 1965 roku, która ma opracować projekt nowego Ratio Studiorum, rkps.

Suszyński W., Jednostka a społeczeństwo. Przyczynek do studiów socjologicznych, Wilno 1929.

Szot A., Pasterze białostockiego Kościoła - ks. Mieczysław Paszkiewicz o biskupach: Adamie Sawickim i Władysławie Suszyńskim, „Studia Teologiczne. Białystok, Łomża, Drohiczyn", 27 (2009). 